\title{
Breast Cancer Screening: Why Not Do it Even During Pregnancy?
}

\author{
Martina Marveggio and Giorgio M Baratelli* \\ Accademia di Senologia di Gravedona, Italy
}

Submission: December 18, 2019; Published: December20, 2019

*Corresponding author: Giorgio M Baratelli, Accademia di Senologia di Gravedona, Italy

\section{Introduction}

The incidence of malignant breast cancer in pregnancy is estimated to be one in $1000 / 3000$ pregnancies; it is superior to that of other diseases and malformations towards which some screening tests recommended in pregnancy are addressed.

\section{Materials and Methods}

The main senological and obstetric-gynecological guidelines, currently used in Italy, in Europe and in USA, were examined.

\section{Result}

In none of the guidelines examined is the need for tests for the early diagnosis of breast cancer in pregnant women indicated. Only in the AIOM guidelines is the problem of the diagnostic delay of breast cancer in pregnancy.

\section{Discussion}

Breast cancer in pregnant women has important medical and social implications. It is often diagnosed with a delay of 3-6 months, resulting in a worse impact on prognosis. The execution of screening and early diagnosis tests, such as breast examination, breast ultrasound, and any mammogram and biopsy, should they prove necessary, are not considered dangerous and are neither contraindicated for the pregnant woman nor for the fetus.

\section{Conclusion}

In consideration of the frequency of breast cancer during pregnancy and its serious consequences, we believe it is appropriate to include in the guidelines the indication for routine breast monitoring consisting of a breast examination and breast ultrasound, to be carried out in the first trimester, when the breast is still relatively investigable.

\section{References}

1. Padmagirison R, Gajjar K, Spencer C (2010) Management of breast cancer during pregnancy. AJP Rep 12: 186-192.

2. www.journal-surgery.net

3. Durrani S, Akbar S, Heena H (2018) Breast Cancer During Pregnancy. Cureus 10(7): e2941.

4. (2016) Collegio Italiano dei Senologi - Linee Guida 2016- Carcinoma Mammario in Gravidanza.

5. WHO reccomendation on antenatal care.

6. Royal College of Obstetricians and Gynaecologists (2011) Guideline no. 12: Pregnancy and breast cancer.

7. (2011) Ministero della Salute e Istituto Superiore di Sanità-Linee guida 2011 Gravidanza fisiologica.

8. (2019) Collegio Italiano dei Senologi-linee guida Carcinoma mammario in gravidanza (ultimo aggiornamento 31 gennaio 2019).

9. (2005) Linee guida FONCaM (ultima edizione pubblicata nel 2005).

10. (2018) AIOM 2018- Linee Guida Neoplasie Della Mammella edizione.

11. Oeffinger KC, Fontham ETH, Etzioni R, Herzig A, Michaelson JS, et al. (2015) Breast Cancer Screening for Women at Average Risk: 2015 Guideline Update from the American Cancer Society. JAMA 314(15): 1599-1614. 
CC (4) This work is licensed under Creative CC) Commons Attribution 4.0 License BY DOI: 10.19080/JGWH.2019.17.555971
Your next submission with Juniper Publishers will reach you the below assets

- Quality Editorial service

- Swift Peer Review

- Reprints availability

- E-prints Service

- Manuscript Podcast for convenient understanding

- Global attainment for your research

- Manuscript accessibility in different formats

( Pdf, E-pub, Full Tsext, Audio)

- Unceasing customer service

Track the below URL for one-step submission https://juniperpublishers.com/online-submission.php 